(C) The Author(s), 2020. Published by Cambridge University Press for the Arizona Board of Regents on behalf of the University of Arizona. This is an Open Access article, distributed under the terms of the Creative Commons Attribution licence (http://creativecommons.org/licenses/by/4.0/), which permits unrestricted re-use, distribution, and reproduction in any medium, provided the original work is properly cited.

\title{
MARINE RESERVOIR EFFECTS IN SEAL (PHOCIDAE) BONES IN THE NORTHERN BERING AND CHUKCHI SEAS, NORTHWESTERN ALASKA
}

\author{
Joshua Reuther ${ }^{1 *(1)} \cdot$ Scott Shirar ${ }^{1} \cdot$ Owen Mason $^{2} \cdot$ Shelby L Anderson $^{3}$ (1) • \\ Joan B Coltrain ${ }^{4} \cdot$ Adam Freeburg $^{5} \cdot$ Peter Bowers $^{1} \cdot$ Claire Alix $^{6} \cdot$ Christyann M Darwent $^{7}$ • \\ Lauren Norman ${ }^{8}$
}

\begin{abstract}
${ }^{1}$ University of Alaska Museum of the North, Archaeology Department, 1962 Yukon Drive, Fairbanks, AK 997756960 USA

${ }^{2}$ INSTAAR, University of Colorado, Campus Box 450, Boulder, CO 80309-0450 USA

${ }^{3}$ Portland State University, Anthropology Department, P.O. Box 751, Portland, OR 97207-0751 USA

${ }^{4}$ University of Utah, Stable Isotope Facility, Anthropology Department, 260 S. Central Campus Dr., Salt Lake City, UT 84112 USA

${ }^{5}$ National Park Service, Gates of the Arctic National Park and Preserve and Yukon-Charley Rivers National Preserve, 101 Dunkel St., Suite 110, Fairbanks, AK 99701 USA

${ }^{6}$ Université Paris 1 Panthéon-Sorbonne, Département de Histoire de l'art et archéologie, Paris, Île-de-France, France ${ }^{7}$ University of California Davis, Department of Anthropology, 328 Young Hall, One Shields Ave., Davis, CA 95616 USA

${ }^{8}$ University of Kansas, Department of Anthropology, 622 Fraser Hall, 1415 Jayhawk Blvd., Lawrence, KS 66045 USA
\end{abstract}

\begin{abstract}
We explore marine reservoir effects (MREs) in seal bones from the northern Bering and Chukchi Seas regions. Ringed and bearded seals have served as dietary staples in human populations along the coasts of Arctic northeast Asia and North America for several millennia. Radiocarbon $\left({ }^{14} \mathrm{C}\right)$ dates on seal bones and terrestrial materials (caribou, plants seeds, wood, and wood charcoal) were compared from archaeological sites in the Bering Strait region of northwestern Alaska to assess MREs in these sea mammals over time. We also compared these results to ${ }^{14} \mathrm{C}$ dates on modern seal specimens collected in AD 1932 and 1946 from the Bering Sea region. Our paired archaeological samples were recovered from late Holocene archaeological features, including floors from dwellings and cache pits, that date between 1600 and $130 \mathrm{cal} \mathrm{BP} .{ }^{14} \mathrm{C}$ dates on seal bones from the northern Bering and Chukchi Seas show differences $[\mathrm{R}(\mathrm{t})]$ of $800 \pm 140$ years from to their terrestrial counterparts, and deviations of $404 \pm 112$ years $(\Delta R)$ from the marine calibration curve.
\end{abstract}

KEYWORDS: Late Holocene, marine reservoir effect, northwestern Alaska, seals.

\section{INTRODUCTION}

Coastal northern Alaska holds an important place with regard to problems focused on understanding climatic and ecological change, as well as human adaptation and migration across the North American Arctic (Friesen et al. 2013; Tackney et al. 2016). The greater Bering Strait region, in particular, has been a center of prehistoric cultural diversity, interaction and innovation for several thousand years (Mason 1998; Mason and Friesen 2017).

Radiocarbon $\left({ }^{14} \mathrm{C}\right)$ dating of Arctic coastal archaeological sites can be problematic for several reasons, including, but not limited to (1) the use of driftwood or long-lived shrubs that produce older ${ }^{14} \mathrm{C}$ ages, commonly referred to as the "old wood effect," that incorrectly date the archaeological event; (2) organic materials can be preserved for relatively long periods of time (1000s to 10,000 s of years) within permafrost (annually frozen) landscapes and incorporated into archaeological matrices; dating these materials yields erroneously old ages; and (3) some sites and features within sites may not contain terrestrial materials generally preferable for ${ }^{14} \mathrm{C}$ dating, so that marine-derived materials are the only dateable material. In addition, people in

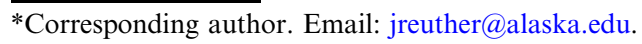


these regions generally had mixed diets that included a large portion of sea mammals and anadromous fish that tend to contribute more marine carbon to their isotopic signature than terrestrial-based sources causing much older ${ }^{14} \mathrm{C}$ ages than the date of a person's death. Thus, understanding the marine reservoir effects (MREs) of different marine mammal species is essential to establishing accurate chronologies for Arctic coastal prehistory (Krus et al. 2019).

Research around Arctic coastlines has focused on estimating regional MREs by either (1) calculating the difference in the ${ }^{14} \mathrm{C}$ content of modern pre-Bomb marine specimens in relation to the calendar year in which they were collected; (2) using ${ }^{14} \mathrm{C}$ dates on ancient marine and terrestrial remains from geological and archaeological deposits that are assumed to be contemporaneous; or (3) comparing ${ }^{14} \mathrm{C}$ dates on marine organisms from geological deposits that contain an established date of a singular depositional event, such as tephra deposition from well-dated volcanic eruptions. Many of these studies show variance in MRE values between different marine species, and fluctuations through time and across regional geography (Arundale 1981; Dyke et al. 1996; Fitzhugh and Brown 2018).

Several attempts have been made at providing corrective MRE values for ${ }^{14} \mathrm{C}$ dates on marine species and human remains from populations that were highly reliant on marine-derived food sources from Arctic coastal zones. Marine mollusks are a focus in many MRE studies and useful in establishing local variations for oceanographic purposes (e.g., Kuzmin et al. 2007; McNeely et al. 2006; Pearce et al. 2017; Martindale et al. 2018). However, marine mollusks are generally not important to Arctic coastal populations as a dietary resource, as indicated by the dearth of mollusks in the archaeological record. Migratory marine mammals, such as seals, walrus and whales, as well as fish, held much more prominent roles in subsistence systems in the Arctic (Park 1994; Saleeby et al. 2009; Darwent 2011; Betts 2016; Coltrain et al. 2016; Britton et al. 2018; Dyke et al. 2019). In the archaeology of coastal high Arctic Canada, ${ }^{14} \mathrm{C}$ dating of marine mammals has been problematic since McGhee and Tuck (1976) discovered that marine-derived dates were older than contemporaneous terrestrial materials such as short-lived shrubs. A similar offset was noted in archaeological samples from northwestern Alaska beach ridge sites (Mason and Ludwig 1990).

Despite this need for accurate and precise MRE values, until the last decade, few researchers sought to understand the differences between ${ }^{14} \mathrm{C}$ dates of marine mammal and terrestrial organisms over time across coastal northern Alaska (notable exceptions include Dumond and Griffin 2002; Khassanov and Savinetsky 2006; Ledger et al. 2016; Krus et al. 2019). In this paper, we document MREs in ${ }^{14} \mathrm{C}$ dated seal remains from several sites spanning the last 1600 years in the Bering Strait and northern Bering Sea and Chukchi Sea regions (Figure 1), encompassing a period of significant cultural and climatic changes during the late Holocene (Mason and Jordan 1993; Mason and Gerlach 1995; Anderson et al. 2018, 2019; Mason et al. 2019). We present both the differences between ${ }^{14} \mathrm{C}$ dated marine-terrestrial pairs, $\mathrm{R}(\mathrm{t})$ values, and from the global marine curve, $\Delta \mathrm{R}$ values (Reimer and Reimer 2017).

\section{REGIONAL SETTING}

The Chukchi Sea and northern Bering Sea are shallow, less than $100 \mathrm{~m}$ deep, and are the flooded continental shelves of the former Beringian subcontinent (Naidu and Gardner 1988). The Holocene transgression followed the flooding of the Bering Strait ca. 11,000 BP (Keigwin et al. 2006) and continued until the establishment of near modern sea level and marine ecology ca. 5000 BP (Jordan and Mason 1999; Khim et al. 2018). Opening north at 


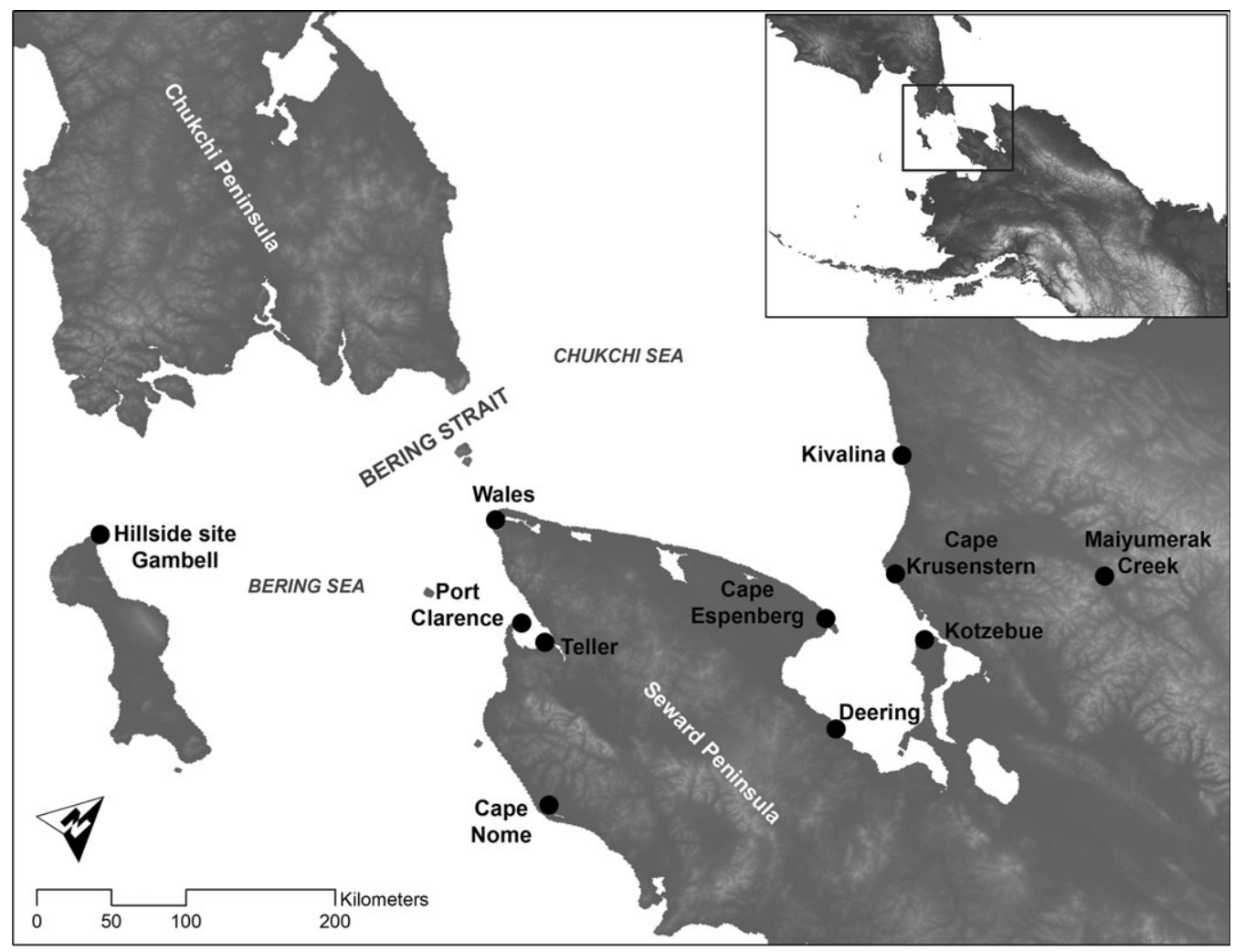

Figure 1 Map of the Bering Strait, northern Bering Sea and Chukchi Sea regions and the study site locations.

$64^{\circ} \mathrm{N}$ at the Bering Strait, the microtidal Chukchi Sea is a triangular shaped compartment of the Arctic Ocean, oriented northwest/southeast and is subject to a complex array of atmospheric and marine processes that include frequent storm surges (Wise et al. 1981) and the intrusion of water masses from both the Pacific and Atlantic Oceans (Coachman and Aagaard 1988; Lee et al. 2007; Pisareva et al. 2015; Pickart et al. 2016). Occasionally, warm, salty Atlantic water reaches the northern Chukchi Sea due to upwelling from Herald Canyon and southward transport along the Siberian coast. Several water masses flow through Bering Strait (Pisareva et. al. 2015) and provide organic carbon onto the Chukchi shelf; on the west, the Bering Sea and Anadyr water masses contribute old carbon derived from the world ocean (Grebmeier and McRoy 1989). Organic carbon from Alaskan rivers is discharged into the eastern water mass (Grebmeier and McRoy 1989); the geostrophically propelled Alaska current that continues along the northwest coast of Alaska spiraling into the shallow embayment of Kotzebue Sound (Aagaard 1987). The current regime produces an upwelling of benthic nutrients (Grebmeier and McRoy 1989; Walsh et al. 1989) and supports a high biomass of iceobligate migrating sea mammals (e.g., seal, walrus, and whale [Lentfer 1988]), critically important to human subsistence, with discarded bone deposited near former settlements. While benthic organic carbon concentration varies across the shelf (Naidu et al. 2004), the organic carbon absorption by sea mammals is diluted by migration. 


\section{Previous Marine Reservoir Effect Estimates in the Bering Strait}

Meyer Rubin (1974) of the U.S. Geological Survey obtained two ${ }^{14} \mathrm{C}$ ages on the valve of a living Astarte borealis dredged from the floor of the Bering Sea in 1969 and obtained an averaged ${ }^{14} \mathrm{C}$ age of $540 \pm 200$ BP (W-2768), providing the first "disconcerting" confirmation that MRE should be a concern in the western Arctic (Rowland 1972). Knowledge of the marine carbon offset led Mason and Ludwig (1990) to compare marine and non-marine archaeological materials from St. Lawrence Island and Cape Krusenstern, noting an offset of between 400 to 500 years. Since 2000, several studies estimated MREs in the Bering Strait and northern Bering Sea. Dumond and Griffin (2002) calculated R(t) values from ${ }^{14} \mathrm{C}$ dates on seal, walrus and whale bones and mussel shells and their terrestrial counterparts-grass, wood, charcoal, and peat samples - in the same archaeological contexts (e.g., strata and features). Dumond and Griffin (2002) obtained a wide range of R(t) values across the Alaska side of the Bering Sea, from the southern Seward Peninsula to the western Alaska Peninsula, spanning $383 \pm 77$ to $783 \pm 50$ years. Their data also displayed a difference of $330 \pm 41$ years between walrus-ivory and seal bone ${ }^{14} \mathrm{C}$ dates, and mussel shells. Dumond and Griffin (2002) did not calculate $\Delta \mathrm{R}$ values from their data.

Khassanov and Savinetsky (2006) calculated $\mathrm{R}(\mathrm{t})$ values between marine-terrestrial pairs from archaeological deposits on the northeastern coast of the Chukchi Peninsula in Siberia. This study used ${ }^{14} \mathrm{C}$ ages on whale bones and baleen, human hair and unidentified sea-mammal bones and produced a wide range of $\mathrm{R}(\mathrm{t})$ values from $220 \pm 202$ to $927 \pm 52$ years. They subsequently calculated $\Delta \mathrm{R}$ values for the northern Bering Sea using their Chukchi Peninsula estimates and Dumond and Griffin's (2002) data from St. Lawrence Island, Wales and Teller. Khassanov and Savinetsky (2006) suggest that an average $\Delta R$ value of $188 \pm 27$ years be used as an MRE correction for the northern Bering Sea region.

McNeely et al. (2006) ${ }^{14} \mathrm{C}$ dated marine mollusk (Hiatella, Mytilus, Serripes, and Mya sp.) shells that were collected live in 1913 around the Chukchi and Bering Seas. Four Hiatella arctica and Mytilus edulis shells from Port Clarence and Teller on the southern Seward Peninsula near the Bering Strait were dated. $\mathrm{R}(\mathrm{t})$ values from these four specimens range from $700 \pm 50$ to $930 \pm 40$ years, and $\Delta \mathrm{R}$ values between $350 \pm 50$ and $580 \pm 40$ years with a weighted mean of $486 \pm 65$ years. In a marine core from the Chukchi Sea, just north of the Bering Strait, Pearce et al. (2017) calculated similar $\Delta \mathrm{R}$ value of $477 \pm 60$ years based a comparison of ${ }^{14} \mathrm{C}$ dates on Macoma sp. shells in close association with an Aniakchak tephra deposit that has a known age of $\sim 3600$ cal BP.

\section{MATERIALS AND METHODS}

\section{Sample Selection}

We ${ }^{14} \mathrm{C}$ dated marine-terrestrial paired samples from archaeological sites along the coast of northwestern Alaska and surrounding the Bering Strait: Cape Espenberg, Cape Krusenstern, Deering, Kivalina, and Kotzebue (Figure 1). This broad sampling across the region allowed us to assess geographic differences in ${ }^{14} \mathrm{C}$ offsets between seals and terrestrial samples, and compare reservoir values from previous research on shell, seals, walrus and whales in the Chukchi Sea, Bering Strait, and northern regions of the Bering Sea. Paired dates from several different periods over the last 1600 cal BP years were compared to understand potential MRE changes through time.

Our study hinges on the selection of closely associated seal and terrestrial samples in welldefined archaeological features, including house floors and fill, and cache pits (Table 1; see 
Table 1 Summary of ${ }^{14} \mathrm{C}$ samples by locations.

\begin{tabular}{|c|c|c|c|c|c|c|}
\hline \multirow[b]{2}{*}{ Location (site, feature) } & \multicolumn{2}{|c|}{ Seals } & \multicolumn{2}{|r|}{ Caribou } & \multicolumn{2}{|c|}{ Charcoal/wood/seed } \\
\hline & ${ }^{14} \mathrm{C}$ age $\mathrm{BP}$ & Lab ID & ${ }^{14} \mathrm{C}$ age $\mathrm{BP}$ & Lab ID & $\begin{array}{l}{ }^{14} \mathrm{C} \text { age } \\
\text { (BP) }\end{array}$ & Lab ID \\
\hline $\begin{array}{l}\text { Cape Espenberg } \\
\text { (KTZ-087, House 68A) }\end{array}$ & $1343 \pm 28$ & AA97494 & $\begin{array}{l}250 \pm 40 \\
355 \pm 27 \\
360 \pm 40\end{array}$ & $\begin{array}{l}\text { Beta-286171* AA97493 } \\
\text { Beta-286172 }\end{array}$ & $\begin{array}{l}395 \pm 15 \\
480 \pm 30\end{array}$ & $\begin{array}{c}\text { OS-96067 } \\
\text { Beta-347937 }\end{array}$ \\
\hline $\begin{array}{l}\text { Cape Espenberg } \\
\text { (KTZ-087, House 87) }\end{array}$ & $1422 \pm 30$ & AA97492 & $551 \pm 42$ & AA97491 & $485 \pm 20$ & OS-96130 \\
\hline $\begin{array}{l}\text { Cape Espenberg } \\
\text { (KTZ-304, F21) }\end{array}$ & $\begin{array}{l}1599 \pm 45 \\
1671 \pm 45\end{array}$ & $\begin{array}{l}\text { AA97488 } \\
\text { AA97490 }\end{array}$ & $\begin{array}{l}640 \pm 40 \\
650 \pm 15 \\
660 \pm 30 \\
670 \pm 15 \\
680 \pm 40 \\
685 \pm 15 \\
710 \pm 20 \\
715 \pm 15 \\
730 \pm 42 \\
923 \pm 43\end{array}$ & $\begin{array}{l}\text { Beta-286169 } \\
\text { UCIAMS-184426 } \\
\text { Beta-453398 } \\
\text { UCIAMS-184430 } \\
\text { Beta-286168 } \\
\text { UCIAMS-184428 } \\
\text { UCIAMS-184427 } \\
\text { UCIAMS-184429 } \\
\text { AA97487 } \\
\text { AA97489* }\end{array}$ & - & - \\
\hline $\begin{array}{l}\text { Cape Krusenstern } \\
\text { (NOA-0463, } \\
\text { House 4A) }\end{array}$ & $880 \pm 30$ & Beta-326111 & $60 \pm 30$ & Beta-326112 & - & - \\
\hline $\begin{array}{l}\text { Cape Krusenstern } \\
\text { (NOA-473, } \\
\text { Cache Pit 1A) }\end{array}$ & $1550 \pm 30$ & Beta-326113 & $840 \pm 25$ & OS-81578 & - & - \\
\hline $\begin{array}{l}\text { Cape Krusenstern } \\
\text { (NOA-474, Unidentified 1B) }\end{array}$ & $810 \pm 30$ & Beta-326119 & $210 \pm 30$ & Beta-326114 & - & - \\
\hline $\begin{array}{l}\text { Cape Krusenstern } \\
\text { (NOA-513, House 10) }\end{array}$ & $1170 \pm 30$ & Beta-326109 & - & - & $280 \pm 40$ & Beta-223219 \\
\hline $\begin{array}{l}\text { Cape Krusenstern } \\
\text { (NOA-513, House 2) }\end{array}$ & $1020 \pm 30$ & Beta-326106 & - & - & $400 \pm 40$ & Beta-226149 \\
\hline
\end{tabular}




\begin{tabular}{|c|c|c|c|c|c|c|}
\hline \multirow[b]{2}{*}{ Location (site, feature) } & \multicolumn{2}{|c|}{ Seals } & \multicolumn{2}{|r|}{ Caribou } & \multicolumn{2}{|c|}{ Charcoal/wood/seed } \\
\hline & ${ }^{14} \mathrm{C}$ age $\mathrm{BP}$ & Lab ID & ${ }^{14} \mathrm{C}$ age $\mathrm{BP}$ & Lab ID & $\begin{array}{l}{ }^{14} \mathrm{C} \text { age } \\
\text { (BP) }\end{array}$ & Lab ID \\
\hline $\begin{array}{l}\text { Cape Krusenstern } \\
\text { (NOA-513, House 4) }\end{array}$ & $1110 \pm 30$ & Beta-326107 & - & - & $570 \pm 40$ & Beta-226151 \\
\hline $\begin{array}{l}\text { Cape Krusenstern } \\
\text { (NOA-513, Activity Area } \\
\text { 361XH070108A) }\end{array}$ & $2230 \pm 30$ & Beta-326105 & - & - & $1590 \pm 40$ & Beta-223220 \\
\hline $\begin{array}{l}\text { Cape Krusenstern } \\
\text { (NOA-538, House 2) }\end{array}$ & $1020 \pm 30$ & Beta-326106 & - & - & $400 \pm 40$ & Beta-226149 \\
\hline $\begin{array}{l}\text { Cape Krusenstern } \\
\text { (NOA-558, House 1A) }\end{array}$ & $1450 \pm 30$ & Beta-326116 & $510 \pm 30$ & Beta-326115 & - & - \\
\hline $\begin{array}{l}\text { Cape Krusenstern } \\
\text { (NOA-558, Unidentified 3B) }\end{array}$ & $1280 \pm 30$ & Beta-326118 & - & - & $765 \pm 35$ & OS-96756 \\
\hline $\begin{array}{l}\text { Cape Krusenstern } \\
\text { (NOA-558, Unidentified 7B) }\end{array}$ & $1410 \pm 30$ & Beta-326117 & $640 \pm 30$ & Beta-326120 & - & - \\
\hline Cape Nome & $830 \pm 20$ & UGAMS21160 & - & - & - & - \\
\hline $\begin{array}{l}\text { Deering } \\
\text { (KTZ-299, } \\
\text { Ipiutak house) }\end{array}$ & $\begin{array}{l}2007 \pm 46 \\
2024 \pm 46\end{array}$ & $\begin{array}{l}\text { AA97484 } \\
\text { AA97486 }\end{array}$ & $\begin{array}{l}1220 \pm 40 \\
1310 \pm 45\end{array}$ & $\begin{array}{c}\text { Beta-231493 } \\
\text { AA97485 }\end{array}$ & $1250 \pm 40$ & Beta-138562 \\
\hline $\begin{array}{l}\text { Deering } \\
\quad \text { (KTZ-300, House 1) }\end{array}$ & $\begin{array}{l}1566 \pm 28 \\
1633 \pm 32 \\
1669 \pm 40 \\
1680 \pm 28\end{array}$ & $\begin{array}{l}\text { AA97497* } \\
\text { AA97495 } \\
\text { AA97496 } \\
\text { AA97498 }\end{array}$ & $\begin{array}{l}830 \pm 40 \\
850 \pm 40 \\
870 \pm 40 \\
900 \pm 40\end{array}$ & $\begin{array}{l}\text { Beta-224229 } \\
\text { Beta-224231 } \\
\text { Beta-224232 } \\
\text { Beta-224230 }\end{array}$ & $\begin{array}{l}870 \pm 40 \\
920 \pm 40\end{array}$ & $\begin{array}{l}\text { Beta-138568 } \\
\text { Beta-138565 }\end{array}$ \\
\hline $\begin{array}{l}\text { Deering } \\
\text { (KTZ-301, House 2) }\end{array}$ & $\begin{array}{l}1682 \pm 45 \\
1718 \pm 51\end{array}$ & $\begin{array}{l}\text { AA97483 } \\
\text { AA97482 }\end{array}$ & $\begin{array}{l}817 \pm 43 \\
827 \pm 42\end{array}$ & $\begin{array}{l}\text { AA97481 } \\
\text { AA97480 }\end{array}$ & $790 \pm 40$ & Beta-189091 \\
\hline $\begin{array}{l}\text { Kivalina } \\
\text { (NOA-362, Ipiutak "wooden } \\
\text { feature") }\end{array}$ & $\begin{array}{l}2262 \pm 47 \\
2327 \pm 47 \\
2336 \pm 47 \\
2340 \pm 47\end{array}$ & $\begin{array}{l}\text { AA97477 } \\
\text { AA97478 } \\
\text { AA97479 } \\
\text { AA97476 }\end{array}$ & $1470 \pm 40$ & Beta-266435 & - & - \\
\hline
\end{tabular}


Table 1 (Continued)

\begin{tabular}{|c|c|c|c|c|c|c|}
\hline \multirow[b]{2}{*}{ Location (site, feature) } & \multicolumn{2}{|c|}{ Seals } & \multicolumn{2}{|r|}{ Caribou } & \multicolumn{2}{|c|}{ Charcoal/wood/seed } \\
\hline & ${ }^{14} \mathrm{C}$ age $\mathrm{BP}$ & Lab ID & ${ }^{14} \mathrm{C}$ age $\mathrm{BP}$ & Lab ID & $\begin{array}{l}{ }^{14} \mathrm{C} \text { age } \\
(\mathrm{BP})\end{array}$ & Lab ID \\
\hline $\begin{array}{l}\text { Kotzebue } \\
\text { (KTZ-031, House 3) }\end{array}$ & $1150 \pm 20$ & UGAMS20318 & $340 \pm 20$ & UGAMS20319 & - & - \\
\hline $\begin{array}{l}\text { Kotzebue } \\
\text { (KTZ-036, House Pit 3) }\end{array}$ & $\begin{array}{l}1537 \pm 48 \\
1642 \pm 48\end{array}$ & $\begin{array}{l}\text { AA100195 } \\
\text { AA97475 }\end{array}$ & $\begin{array}{l}313 \pm 42 \\
660 \pm 47 \\
743 \pm 31\end{array}$ & $\begin{array}{l}\text { AA97475* } \\
\text { AA100198 } \\
\text { AA101140 }\end{array}$ & - & - \\
\hline $\begin{array}{l}\text { Kotzebue } \\
\quad \text { (KTZ-036, } \\
\text { House Pit 8) }\end{array}$ & $1150 \pm 20$ & UGAMS41355 & $230 \pm 30$ & UGAMS41354 & - & - \\
\hline $\begin{array}{l}\text { Maiyumerak Creek } \\
\text { (XBM-131, } \\
\text { House Pit } 8)\end{array}$ & $1350 \pm 20$ & UGAMS20320 & $\begin{array}{l}170 \pm 50 \\
280 \pm 40 \\
280 \pm 40 \\
325 \pm 40\end{array}$ & $\begin{array}{l}\text { Beta-223359 } \\
\text { Beta-223358 } \\
\text { Beta-228015 } \\
\text { CAMS-142693 }\end{array}$ & - & - \\
\hline St. Lawrence Island & $860 \pm 20$ & UGAMS21161 & - & - & - & 一 \\
\hline
\end{tabular}


also Supplemental Information for detailed site information). Some features, such as the house Features 21 and 87 at Cape Espenberg, had multiple occupations, and potential reuse, that were distinguished in the stratigraphy and through ${ }^{14} \mathrm{C}$ dating. In these contexts, paired samples were only used if they were from the same excavation units, stratigraphic levels and depths in order to minimize the potential combining of ${ }^{14} \mathrm{C}$ dates from different occupational episodes.

Terrestrial samples consist of caribou remains, wood, wood charcoal fragments, and plant seeds. A total of $84{ }^{14} \mathrm{C}$ dates were compiled for this study: 34 on seal bones, 37 on caribou bones, and 13 on wood, wood charcoal fragments, and seeds (see Supplemental Table S1 for individual date information).

The context of each sample was scrutinized to avoid the selection of samples from archaeological features that potentially had multiple periods of deposition (i.e., long periods of occupation) or post-depositional disturbance. In instances with more than three dates on terrestrial or marine samples from an archaeological feature, we statistically compared dates (described below) to identify potential outliers within the groups. Outlier ${ }^{14} \mathrm{C}$ dates can occur from subtle differences in depositional contexts that create the mixture of two different periods of materials, by exogenous contamination that was not fully removed from samples during pretreatments, or by laboratory error. Outlier dates can increase the inaccuracy of local reservoir values (Ascough et al. 2009). Outliers were removed from the study prior to calculating MRE values for seals. The total number of outliers and marineterrestrial pairs are discussed below.

In addition to the archaeological samples, we ${ }^{14} \mathrm{C}$ dated two seal (Erignathus barbatus and Pusa hispida) skulls collected by Otto William Geist in AD 1932 and 1946 from Cape Nome and the St. Lawrence Island region. These modern-aged specimens are housed in the Mammals Collection at the University of Alaska Museum of the North. The archaeology sites and features and the modern seal crania are described in more detail in the Supplemental Materials.

\section{Laboratory Methods}

${ }^{14} \mathrm{C}$ AMS ages were assayed at six different labs: Beta Analytic, Inc., Center for Accelerator Spectrometry at Lawrence Livermore National Laboratory, Center for Applied Isotope Studies at the University of Georgia, the National Ocean Sciences AMS Facility, W.M. Keck Carbon Cycle Accelerator Mass Spectrometer Facility at the University of California Irvine, and the University of Arizona Accelerator Mass Spectrometry Laboratory. The species and skeletal element of each bone were identified by zooarchaeologists Carol Gelvin-Reymiller, then of Northern Land Use Research, Inc., and Dr. Holly McKinney of the University of Alaska Fairbanks, in addition to several of the coauthors on this paper (CD, AF, LN). We ideally aimed to sample from multiple individuals of caribou and seals from each archaeological feature to account for some variability within a species at any given particular time.

Seventy-one bones were sampled with pretreatments conducted at ${ }^{14} \mathrm{C}$ labs $(\mathrm{n}=37)$, and by Joan Coltrain at the Archaeological Center Research Facility for Stable Isotope Chemistry at the University of Utah $(n=34)$. All of the sites used in this study have substrates (such as perennially frozen ground) in Arctic settings that generally promotes relatively slow diagenetic changes in organic materials. Bones in these settings are typically well-preserved. Nevertheless, the atomic C:N ratios and collagen yields by weight (\%yield) were measured for 41 of the 71 bone samples $(58 \%)$ to establish the pattern of collagen diagenesis and 
potential for significant amounts of exogenous carbon contamination to alter the ${ }^{14} \mathrm{C}$ ages. The methods used by each lab to pretreat samples and conduct stable isotope and ${ }^{14} \mathrm{C}$ AMS and stable isotope measurements are provided in the Supplementary Materials.

\section{Statistical Approaches}

Groups of dates on either marine or terrestrial samples from the same archaeological feature were evaluated for statistical similarities using the $\chi^{2}$ tests (Ward and Wilson 1978; Ascough et al. 2009) in Calib 7.1 (Stuiver et al. 2013). Groups of dates that showed statistically different results were then segregated into individual $\chi^{2}$ test comparisons to distinguish possible outliers within the groups (Table S2 in Supplementary Materials). Outliers were subsequently removed from the analysis (Table 1). Statistically similar dates for marine and terrestrial sample groups within features were combined into weighted mean ages using Calib 7.1 (Ward and Wilson 1978). Several features $(n=13)$ had only single sets of marine and terrestrial ${ }^{14} \mathrm{C}$ dates.

Paired samples from features at sites were grouped by a general location and into four periods based on the ${ }^{14} \mathrm{C}$ age $\mathrm{BP}$ of a pair's terrestrial sample: $>200 \mathrm{BP}, 200-600 \mathrm{BP}, 600-1000 \mathrm{BP}$, and 1100-1600 BP. The two historic samples from St. Lawrence Island and Cape Nome were defined as "Modern" considering the recorded dates of their collection in AD 1932 and 1946. Supplementary Materials Tables S4 through S8 provide detailed information on ${ }^{14} \mathrm{C}$ pairs by general location and by the four periods.

We define $\mathrm{R}(\mathrm{t})$ as the difference, or offset, between paired marine and terrestrial (assumed "atmospheric") ${ }^{14} \mathrm{C}$ ages, along with the associated standard errors of the differences (Stuiver et al. 1986; Taylor and Bar-Yosef 2014: 152). $\mathrm{R}(\mathrm{t})$ is calculated by subtracting the marine ${ }^{14} \mathrm{C}$ age from the associated terrestrial ${ }^{14} \mathrm{C}$ age. $\mathrm{R}(\mathrm{t})$ values for the two modern seal samples collected in 1932 and 1946 were calculated by subtracting the expected ${ }^{14} \mathrm{C}$ age in IntCal13 (Reimer et al. 2013) that is associated with the calendrical terrestrial date of collection.

$\Delta \mathrm{R}$ weighted mean values and standard deviations were calculated using the deltar function in the Marine Radiocarbon Database from the 14CHRONO Centre (Reimer and Reimer 2017). Modern seal $\Delta \mathrm{R}$ values were calculated using the known collection date as the independent age determination. $\Delta \mathrm{R}$ values for archaeological paired marine-terrestrial samples $>200 \mathrm{BP}$ were calculated in deltar, outlined in Reimer and Reimer (2017) using the Northern Hemisphere curve. Because the deltar program cannot calculate $\Delta \mathrm{R}$ values for paired-samples with terrestrial pairs that have ages $<200 \mathrm{BP}$, we followed procedures outlined in Southon et al. (1995) to derive $\Delta \mathrm{R}$ values for these pairs. Terrestrial ${ }^{14} \mathrm{C}$ ages $<200 \mathrm{BP}$ were calibrated in OxCal v4.3 (Bronk Ramsey 2009) using IntCal13, then terrestrial calibrated age range was converted to modelled ${ }^{14} \mathrm{C}$ ages using the Marine14 curve (Reimer et al. 2013). The Marine14 modelled ${ }^{14} \mathrm{C}$ age was subtracted from the original ${ }^{14} \mathrm{C}$ age of the marine sample of the marine-terrestrial pair to produce a $\Delta \mathrm{R}$ value. Weighted means and errors (the square root of the sum of squares of individual uncertainties) were calculated for $R(t)$ and $\Delta \mathrm{R}$ values for a given group, along with overall all $\mathrm{R}(\mathrm{t})$ and $\Delta \mathrm{R}$ values for seals in the Bering Strait and northern Bering Sea region

Shapiro-Wilk tests shows $\mathrm{R}(\mathrm{t})$ and $\Delta \mathrm{R}$ values do not significantly deviate from normal distributions: $\mathrm{R}(\mathrm{t})(\mathrm{n}=23 ; \mathrm{W}=0.973693$; critical $\mathrm{W}$ value $=0.914154 ; \mathrm{p}=0.776418)$, and $\Delta \mathrm{R}(\mathrm{n}=23 ; \mathrm{W}=0.92713$; critical $\mathrm{W}$ value $=0.914154 ; \mathrm{p}=0.094824)$. One-way analysis of variance (ANOVA) with Tukey HSD post-hoc tests were used to assess variation within and across groups of $\mathrm{R}(\mathrm{t})$ and $\Delta \mathrm{R}$ values. $\mathrm{R}(\mathrm{t})$ and $\Delta \mathrm{R}$ values for 
Dumond and Griffin (2002), Khassanov and Savinetsky (2006), and McNeely et al. (2006) were also recalculated using the same procedures outlined above for reliable comparisons to our study's results (Tables S9 and S10). ANOVA and Tukey HSD post-hoc tests were used to assess variation among our study's overall $\mathrm{R}(\mathrm{t})$ and $\Delta \mathrm{R}$ values and those from the previous studies.

\section{RESULTS AND DISCUSSION}

\section{Quality Control of Bone Samples and Radiocarbon Data}

The atomic C:N ratios and collagen yields for $58 \%$ of the study's bone samples were scrutinized to assess the potential for severe protein degradation and for significant amounts of exogenous carbon contamination that would alter the ${ }^{14} \mathrm{C}$ ages. Atomic $\mathrm{C}: \mathrm{N}$ ratios are between 3.1 and 3.5 with an average of $3.3 \pm 0.1$ falling within the recommended ranges of 2.9-3.5 or 3.1-3.5 for accepting collagen as preserved enough to yield an accurate ${ }^{14} \mathrm{C}$ age (DeNiro 1985; van Klinken 1999).

Collagen yields on these samples are between $2.3 \%$ and $31.0 \%$ yield, with an average of $17.6 \pm$ $6.4 \%$ yield, well above acceptable levels $>1$-to-3.5\%yield for well-preserved collagen (Ambrose 1990; van Klinken 1999). Therefore, we consider the collagen quality to be high and exogenous carbon contamination to be minimal in contributing to inaccurate ${ }^{14} \mathrm{C}$ ages.

Chi-square tests for within groups of terrestrial and marine dates from a given feature were also preformed to define and reduce the influence of outliers on $\mathrm{R}(\mathrm{t})$ and $\Delta \mathrm{R}$ values (Ascough et al. 2009) (Table S2). Five of the $84(5.9 \%){ }^{14} \mathrm{C}$ dates were removed due to internal inconsistencies (outliers) within groups of terrestrial and marine samples within a given feature (Table 1). Four bone ages (three caribou and one seal) were removed from the data set, as well as one ${ }^{14} \mathrm{C}$ date on a piece of structural wood in the tunnel of a house feature at Cape Espenberg that may be driftwood.

As a result, the total included 80 paired samples after the statistical outliers were removed from the total data set. Features with multiple ${ }^{14} \mathrm{C}$ dates on terrestrial and marine samples that were statistically similar were subsequently averaged to create 24 marine-terrestrial paired data sets to use in our calculations of $\mathrm{R}(\mathrm{t})$ and $\Delta \mathrm{R}$. Paired data sets are distributed across the general localities of the study area by the following (from highest to lowest amount): 11 at Cape Krusenstern, three at Deering, three at Cape Espenberg, three at Kotzebue, one at Kivalina, one at Maiyumerak Creek, and the sole modern sets from St. Lawrence Island and Cape Nome regions. When divided by general periods, the paired data sets are distributed as such (from most recent to oldest periods): three $<200 \mathrm{BP}, 10$ between 200-600 BP, seven between 600-1000 BP, and four between 1000-1600 BP.

\section{$R(t)$ and $\Delta R$ values across general periods and locations across the northern Bering Sea.}

$\mathrm{R}(\mathrm{t})$ and $\Delta \mathrm{R}$ values for each pair and feature and ANVOA and Tukey HSD results for groups are detailed in the Supplemental Materials (Tables S4 through S8).

\section{General Periods}

Weighted means for $\mathrm{R}(\mathrm{t})$ values by period are between $875 \pm 155$ and $699 \pm 50$ years, a span of 176 years, with an overall weighted mean of $800 \pm 140$ years (Table 2; Figure 2). Weighted mean $\Delta \mathrm{R}$ values are between $429 \pm 148$ and $384 \pm 90$ years, a 45-year span, with an overall weighted mean of $404 \pm 112$ years. The weighted means of the $R(t)$ and $\Delta R$ values show significant variation within 2 out of the 4 periods (Table S4). However, there is little 
Table $2 \mathrm{R}(\mathrm{t})$ and $\Delta \mathrm{R}$ values across locations and by period.

\begin{tabular}{|c|c|c|c|c|}
\hline $\begin{array}{l}\text { Location } \\
\text { (site, feature) }\end{array}$ & Marine sample $\left({ }^{14} \mathrm{C} \mathrm{BP}\right)$ & Atmospheric sample $\left({ }^{14} \mathrm{C} \mathrm{BP}\right)$ & $\begin{array}{l}\mathrm{R}(\mathrm{t}) \\
(1 \sigma)\end{array}$ & $\begin{array}{c}\Delta \mathrm{R} \\
(1 \sigma)\end{array}$ \\
\hline \multicolumn{5}{|l|}{ Cape Espenberg } \\
\hline KTZ-087, House 68A & $1343 \pm 28$ & $383 \pm 12^{*}$ & $960 \pm 30$ & $498 \pm 36$ \\
\hline KTZ-304, House 21 & $1635 \pm 32 *$ & $683 \pm 7^{*}$ & $952 \pm 33$ & $524 \pm 33$ \\
\hline Cape Espenberg-overall & & & $948 \pm 18$ & $504 \pm 18$ \\
\hline \multicolumn{5}{|l|}{ Cape Krusenstern } \\
\hline NOA-513, House 10 & $1170 \pm 30$ & $280 \pm 40$ & $890 \pm 50$ & $448 \pm 58$ \\
\hline NOA-513, House 2 & $1020 \pm 30$ & $400 \pm 40$ & $620 \pm 50$ & $169 \pm 55$ \\
\hline NOA-558, House 1A & $1450 \pm 30$ & $510 \pm 30$ & $940 \pm 42$ & $510 \pm 39$ \\
\hline NOA-513, House 4 & $1110 \pm 30$ & $570 \pm 40$ & $540 \pm 50$ & $122 \pm 52$ \\
\hline NOA-558, Unidentified 7B & $1410 \pm 30$ & $640 \pm 30$ & $770 \pm 42$ & $338 \pm 48$ \\
\hline NOA-473, Cache Pit 1A & $1550 \pm 30$ & $840 \pm 25$ & $710 \pm 39$ & $334 \pm 41$ \\
\hline \multicolumn{5}{|l|}{ Deering } \\
\hline KTZ-301, House 2 & $1698 \pm 34^{*}$ & $811 \pm 25^{*}$ & $887 \pm 42$ & $510 \pm 40$ \\
\hline KTZ-300, House 1 & $1662 \pm 19^{*}$ & $873 \pm 17^{*}$ & $789 \pm 25$ & $422 \pm 30$ \\
\hline KTZ-299, Ipiutak house & $2016 \pm 33^{*}$ & $1256 \pm 24^{*}$ & $760 \pm 41$ & $359 \pm 47$ \\
\hline Deering_overall & & & $803 \pm 54$ & $434 \pm 66$ \\
\hline \multicolumn{5}{|l|}{ Kivalina } \\
\hline NOA-362, Ipiutak wooden feature & $2316 \pm 24^{*}$ & $1470 \pm 40$ & $846 \pm 47$ & $491 \pm 43$ \\
\hline Kotzebue & & & & \\
\hline KTZ-036, House Pit 8 & $1150 \pm 20$ & $230 \pm 20$ & $872 \pm 28$ & $487 \pm 26$ \\
\hline
\end{tabular}




\begin{tabular}{|c|c|c|c|c|}
\hline $\begin{array}{l}\text { Location } \\
\text { (site, feature) }\end{array}$ & Marine sample $\left({ }^{14} \mathrm{C} \mathrm{BP}\right)$ & Atmospheric sample $\left({ }^{14} \mathrm{C} \mathrm{BP}\right)$ & $\begin{array}{l}\mathrm{R}(\mathrm{t}) \\
(1 \sigma)\end{array}$ & $\begin{array}{c}\Delta \mathrm{R} \\
(1 \sigma)\end{array}$ \\
\hline KTZ-031, House 3 & $1150 \pm 20$ & $340 \pm 20$ & $920 \pm 28$ & $384 \pm 54$ \\
\hline KTZ-036, House Pit 3 & $1590 \pm 34^{*}$ & $718 \pm 26^{*}$ & $810 \pm 43$ & $462 \pm 38$ \\
\hline Kotzebue-overall & & & $866 \pm 61$ & $466 \pm 42$ \\
\hline Maiyumerak Creek & & & & \\
\hline XBM-131, House Pit 8 & $1350 \pm 20^{*}$ & $274 \pm 21^{*}$ & $1076 \pm 29$ & $644 \pm 50$ \\
\hline St. Lawrence Island & $830 \pm 20$ & $153 \pm 8$ & $677 \pm 22$ & $374 \pm 20$ \\
\hline $\begin{array}{l}\text { Bering Strait seals- } \\
\text { overall by location }\end{array}$ & & & $834 \pm 159$ & $446 \pm 73$ \\
\hline Periods & & & $\begin{array}{l}\mathrm{R}(\mathrm{t}) \\
(1 \sigma)\end{array}$ & $\begin{array}{l}\Delta \mathrm{R} \\
(1 \sigma)\end{array}$ \\
\hline$<200 \mathrm{BP}$ & & & $696 \pm 56$ & $389 \pm 17$ \\
\hline 200-600 BP & & & $875 \pm 155$ & $429 \pm 148$ \\
\hline $600-1000 \mathrm{BP}$ & & & $800 \pm 126$ & $400 \pm 137$ \\
\hline 1200-1600 BP & & & $746 \pm 82$ & $384 \pm 90$ \\
\hline $\begin{array}{l}\text { Bering Strait seals- } \\
\text { overall by period }\end{array}$ & & & $800 \pm 140$ & $404 \pm 112$ \\
\hline
\end{tabular}

KTZ-031, House 3

KTZ-036, House Pit 3

Kotzebue-overall

XBM-131, House Pit 8

Bering Sti

overall by location

$<200$ BP

200-600 BP

$600-1000 \mathrm{BP}$

Bering Strait seals-

*Combined average ages are detailed in Table 1 and Table S2. 

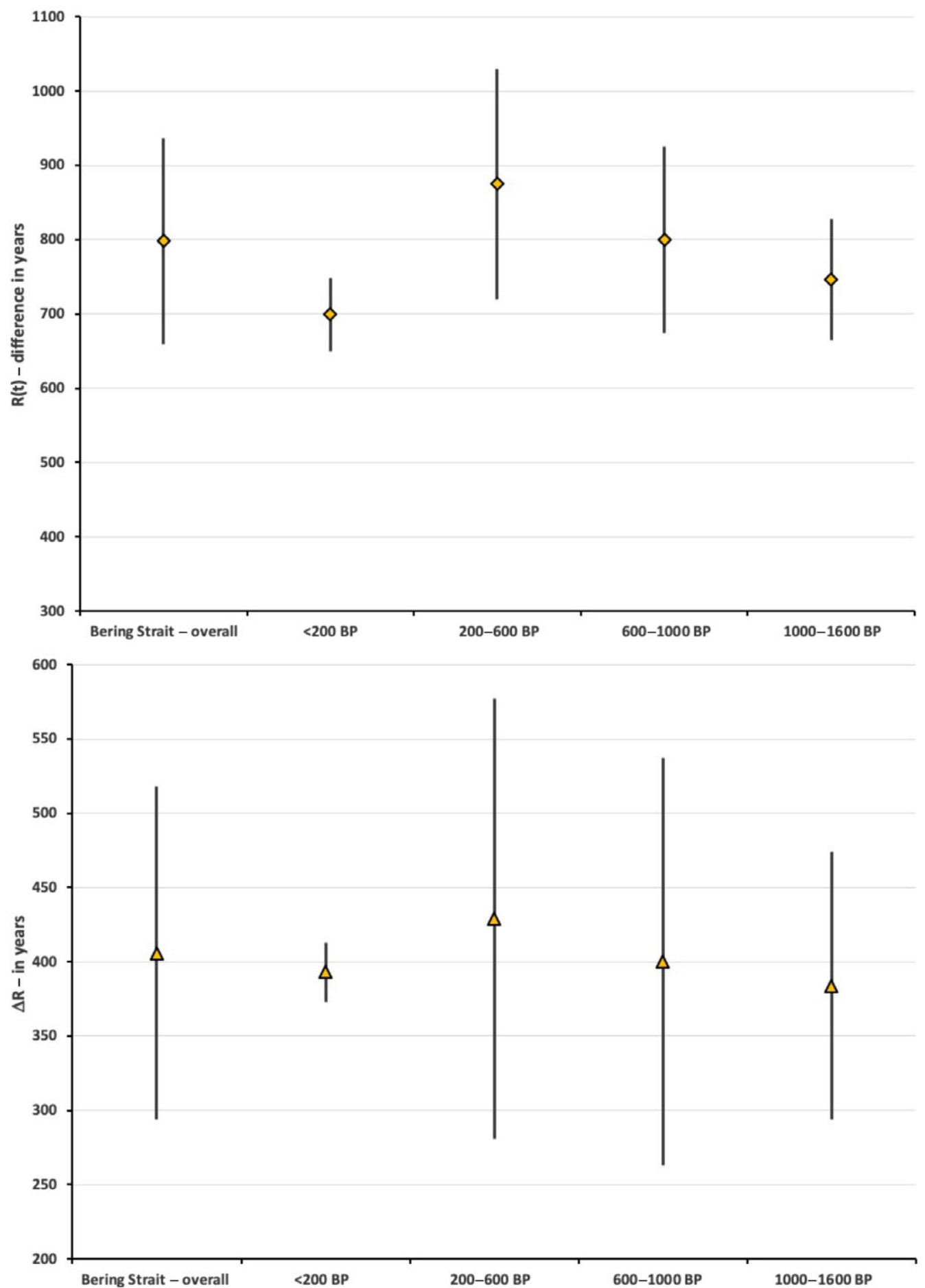

Figure 2 Weighted mean $\mathrm{R}(\mathrm{t})$ (above) and $\Delta \mathrm{R}$ values (below) by general period from this study. Data summarized in Table 2. 
Table 3 Comparison of marine reservoir effect values from studies in northwestern Alaska.

\begin{tabular}{|c|c|c|c|c|}
\hline Location & Taxa/material & $\mathrm{R}(\mathrm{t})(1 \sigma)$ & $\Delta \mathrm{R}(1 \sigma)$ & Reference \\
\hline$\overline{\text { Bering Strait region }}$ & Seal bone $(\mathrm{n}=33)$ & $800 \pm 140$ & $404 \pm 112$ & This study \\
\hline Port Clarence/Teller & $\begin{array}{l}\text { Macoma, Serripes, } \\
\text { Hiatella, Mytilus, } \\
\text { Mya shells }(\mathrm{n}=4)\end{array}$ & $836 \pm 65$ & $486 \pm 65$ & McNeely (2006) \\
\hline $\begin{array}{l}\text { Cape Wales (TEL026 } \\
\text { and TEL079) }\end{array}$ & Seal bone $(n=3)$ & $633 \pm 90$ & $195 \pm 74$ & $\begin{array}{l}\text { Dumond and } \\
\text { Griffin (2002) }\end{array}$ \\
\hline $\begin{array}{l}\text { St. Lawrence Island- } \\
\text { Hillside (XSL-001) }\end{array}$ & Walrus ivory $(\mathrm{n}=4)$ & $621 \pm 118$ & $265 \pm 126$ & $\begin{array}{l}\text { Dumond and } \\
\text { Griffin (2002) }\end{array}$ \\
\hline $\begin{array}{l}\text { St. Lawrence Island- } \\
\text { Gambell Burials }\end{array}$ & Whale bone $(n=6)$ & $546 \pm 193$ & $154 \pm 171$ & $\begin{array}{l}\text { Dumond and } \\
\text { Griffin (2002) }\end{array}$ \\
\hline Chukchi Peninsula & $\begin{array}{l}\text { Whale bones and } \\
\text { baleen, human hair } \\
\text { and unidentified } \\
\text { sea mammal bones } \\
(\mathrm{n}=6)\end{array}$ & $778 \pm 189$ & $350 \pm 201$ & $\begin{array}{l}\text { Khassanov and } \\
\text { Savinetsky } \\
(2006)\end{array}$ \\
\hline
\end{tabular}

variation across the $\mathrm{R}(\mathrm{t})$ and $\Delta \mathrm{R}$ weighted means of the periods $\left(\mathrm{R}(\mathrm{t}) F_{[3,75]}=0.11, p=0.95\right.$; $\left.\Delta \mathrm{R} F_{[3,75]}=0.02, p=1.00\right)$.

\section{By Location}

Weighted mean $\mathrm{R}(\mathrm{t})$ values by location show a spread of $677 \pm 22$ and $948 \pm 18$ years, while $\Delta R$ values range between $302 \pm 138$ and $644 \pm 50$ years (Table 2). $R(t)$ and $\Delta R$ values have overall weighted means of $834 \pm 159$ and $446 \pm 73$ years, respectively. ANOVA values for the weighted means for $\mathrm{R}(\mathrm{t})$ and $\Delta \mathrm{R}$ values show no significant variation across locations $(\mathrm{R}(\mathrm{t})$ $F_{[7,74]}=0.90, p=0.51 ; \Delta \mathrm{R} F_{[7,74]}=0.70, p=0.67$; see Table S4).

The overall $\Delta \mathrm{R}$ weighted mean of $404 \pm 112$ years based on values for the periods should be used as an MRE correction because it takes into account larger uncertainty than the overall $\Delta \mathrm{R}$ value calculated for the locations. As expected, there are changes in the percent differences between the calibrated mean ages for terrestrial and seal samples occurs once the weighted mean of $\Delta \mathrm{R}$ values $404 \pm 112$ years is applied as a corrective measure for seal ${ }^{14} \mathrm{C}$ ages (see Table S4). The percent of change between uncorrected and corrected marine ages $\Delta \mathrm{R}$ is between -83.7 to $-36.8 \%$ for an average of $-54.8 \pm 14.3 \%$. The difference between mean ages of terrestrial and seal calibrated ages range between 428 and 1020 years with percent differences between 40.9 and $149.2 \%$ and an average of $78.9 \pm 29.1 \%$ when a $\Delta R$ value correction is not applied. The mean ages range between -262 and 197 years with percent differences between -57.8 and $46.5 \%$ with an average of $1.1 \pm 23.7 \%$ after the application of the $\Delta \mathrm{R}$ value quoted above.

\section{Comparisons to Previous Studies}

Our weighted mean $\mathrm{R}(\mathrm{t})$ and $\Delta \mathrm{R}$ values are 165-252 years and 143-250 years, respectively, greater than Dumond and Griffin's (2002) values. Our weighted mean $R(t)$ and $\Delta R$ values are 20 and 56 years greater than the Khassanov and Savinetsky (2006) values (Table 3). The weighted means of the McNeely et al. (2006) $R(t)$ and $\Delta R$ values are 38-80 years 

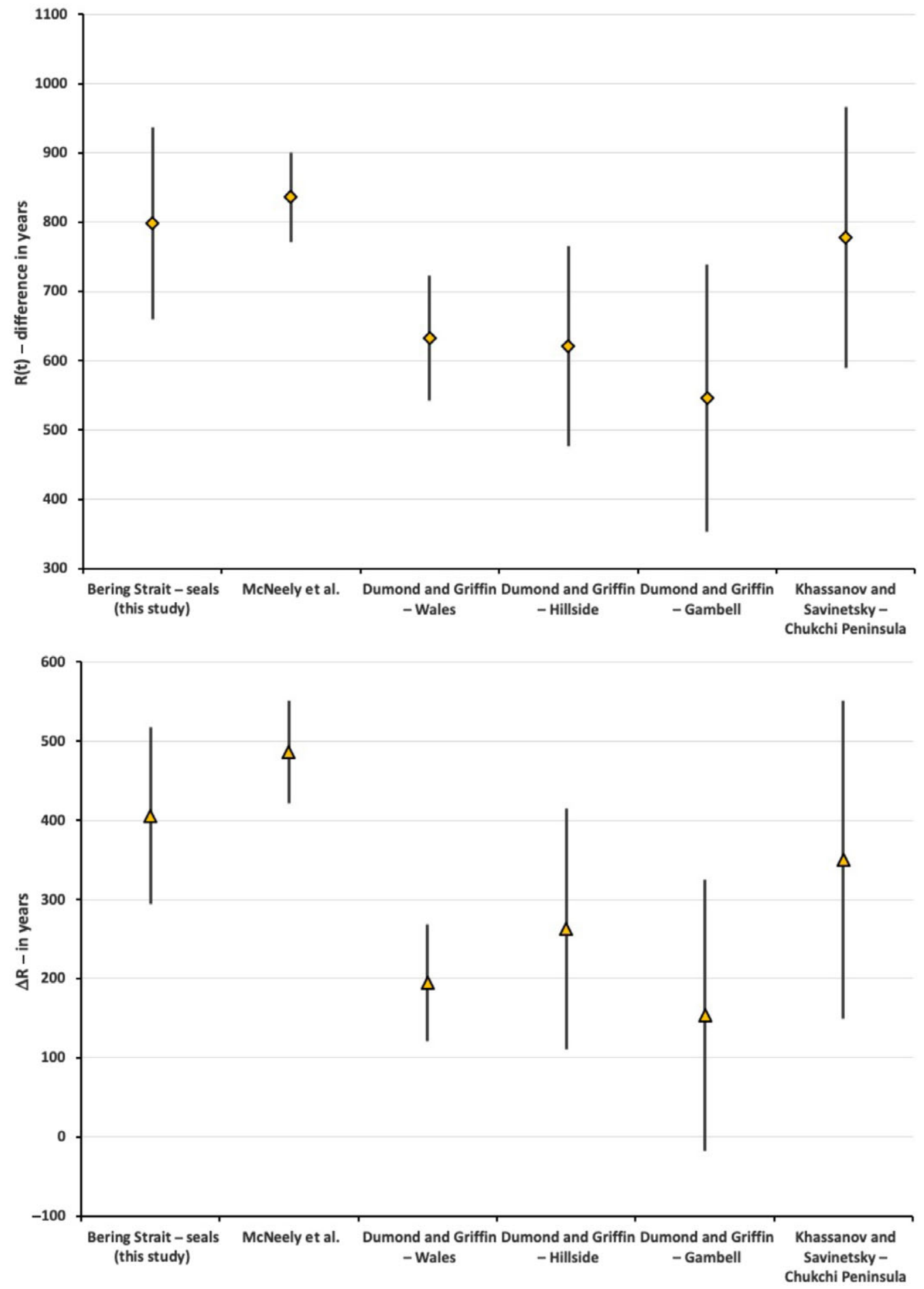

Figure 3 Weighted mean $\mathrm{R}(\mathrm{t})$ (above) and $\Delta \mathrm{R}$ values (below) on Bering Strait seals from this study in comparison to data from McNeely et al. (2006), Dumond and Griffin (2002), and Khassanov and Savinetsky (2006). Data summarized in Table 3. 
greater than ours. However, the large standard errors of weighted mean $\mathrm{R}(\mathrm{t})$ and $\Delta \mathrm{R}$ values for all of the data sets (our study and previous studies) overlap in their ranges displaying little variation (Figure 3). ANOVA values show no significant variation across the $\mathrm{R}(\mathrm{t})$ and $\Delta \mathrm{R}$ values of our study and the previous studies $\left(\mathrm{R}(\mathrm{t}) F_{[5,51]}=0.20, p=0.96 ; \Delta \mathrm{R} F_{[5,51]}=\right.$ $0.31, p=0.90$; see Table S10).

\section{CONCLUSIONS}

Our study provides an assessment of MREs of ${ }^{14} \mathrm{C}$ content among seals in the northern Bering Sea over the last 1600 years. Weighted mean $\mathrm{R}(\mathrm{t})$ and $\Delta \mathrm{R}$ values, given their large uncertainties, display little variation over the last 1600 years and across our sampling locations. The overall $\mathrm{R}(\mathrm{t})$ and $\Delta \mathrm{R}$ weighted means for seal remains in the northern Bering Sea is $800 \pm 140$ and $404 \pm 112$ years, respectively; these values are similar to values calculated on marine mollusks by McNeely et al. (2006) but larger than values calculated on seal, walrus and whale remains by Dumond and Griffin (2002) for the region. If the standard error of predicted values, as suggested by Cook et al. (2015), is applied to the weighted mean to account for increased uncertainty in using archaeological sample association than the $\mathrm{R}(\mathrm{t})$ and $\Delta \mathrm{R}$ values are $800 \pm 202$ and $404 \pm 176$, respectively.

We suggest that the weighted mean $\Delta \mathrm{R}$ value of $404 \pm 112$ years can be used as a local $\Delta \mathrm{R}$ estimate to correct for MREs for ${ }^{14} \mathrm{C}$ ages on seals in the region and for human remains for populations that relied on these types of pinnipeds as a food staple. Our estimate is slightly less than the Krus et al. (2019) value of $450 \pm 84$ years for the Point Barrow area based on paired caribou and seal ${ }^{14} \mathrm{C}$ dates. However, both values overlap at $1 \sigma$.

MRE corrections for human remains should consider the species that provide the largest contributions to a regional population's diet, as well as accounting for potential subsistence preference changes over time. Dietary modeling using stable isotopes of human remains and summaries of zooarchaeological remains from sites for a given period provide a necessary context for which $\Delta \mathrm{R}$ value corrections to use (Coltrain et al. 2016; Krus et al. 2019). The use of an accurate $\Delta \mathrm{R}$ value in corrections can have profound differences in how we interpret changes in the archaeological record (Coltrain et al. 2006; Coltrain 2010; Kuzmin 2010; Misarti and Maschner 2015; West et al. 2019).

\section{ACKNOWLEDGMENTS}

We thank zooarchaeologists Carol Gelvin-Reymiller, then of Northern Land Use Research, Inc., and Dr. Holly McKinney of the University of Alaska Fairbanks for aiding in the identification of seal and caribou remains from many of the study sites. Northern Land Use Research Alaska, Inc. funded ${ }^{14} \mathrm{C}$ ages for the Deering, Kivalina, and Kotzebue sites and modern seal skulls. We thank the Deering, Kivalina, Kotzebue, and Shishmaref communities for supporting these archaeological projects and allowing us to sample these collections for the purpose of this study. Eric Carlson, former NLURA archaeologist, supported us in selection of Kotzebue samples and provided notes on their context. National Park Service supported the Maiyumerak Creek excavations and analyses. The National Park Service also funded research at Cape Krusenstern through a cooperative agreement (J8W07070032) managed by the Pacific Northwest Cooperative Ecosystem Study Unit. The Cape Espenberg research has involved several successive projects, first supported by the National Park Service (1988-1995), and then through two consortia of researchers; the first consortia was supported from 2009-2013 by a National Science 
Foundation (NSF) grant to J. F. Hoffecker, O. K. Mason, C. M. Darwent, and N. H. Bigelow (ARC-0755725), and the second consortia of researchers were supported from 2015-present by a collaborative NSF grant to C. Alix and N. H. Bigelow (ARC-1523160), O.K. Mason (ARC1523205), S. Anderson (ARC-1523059), and D.H. O'Rourke (ARC-1523059). Link Olson and Aren Gunderson of the University of Alaska Museum of the North Mammalogy Lab allowed for sampling of the modern seal skulls from their collection. Brian Hemphill generously advised us on the statistical procedures we used in this study. Sam Coffman drafted the main map for this article. We thank the reviewers that provided extremely valuable comments making this study fundamentally higher in its quality.

\section{SUPPLEMENTARY MATERIAL}

To view supplementary material for this article, please visit https://doi.org/10.1017/RDC. 2020.127

\section{REFERENCES}

Aagaard K. 1987. Physical oceanography of the Chukchi Sea: an overview. In: Chukchi Sea Information Update, June 1987. Outer Continental Shelf Environmental Assessment Program. Alaska Outer Continental Study, MMS 86-0097. Washington D.C.: US Department of the Interior, Minerals Management Service.

Ambrose SH. 1990. Preparation and characterization of bone and tooth collagen for isotopic analysis. Journal of Archaeological Science 17:431-451.

Anderson SL, Jordan J, Freeburg A. 2018. Human settlement and mid-late Holocene coastal environmental change at Cape Krusenstern, Northwest Alaska. Quaternary International. doi: 10.1016/j.quaint.2018.10.028.

Anderson SL, Brown TJ, Junge J, Duelks J. 2019. Demographic fluctuations and the emergence of Arctic maritime adaptations. Journal of Anthropological Archaeology 56:101100. doi: 10.1016/j.jaa.2019.101100

Arundale WH. 1981. Radiocarbon dating in Eastern Arctic archaeology: a flexible approach. American Antiquity 46(2):244-271.

Ascough PL, Cook GT, Dugmore AJ. 2009. North Atlantic marine ${ }^{14} \mathrm{C}$ reservoir effects: implications for late-Holocene chronological studies. Quaternary Geochronology 4:171-180.

Betts MW. 2016. Zooarchaeology and the reconstruction of ancient human-animal relationships in the Arctic. In: Friesen TM, Mason OK, editors. The Oxford handbook of the prehistoric Arctic. New York: Oxford University Press. p. 81-108.

Britton K, McManus-Fry E, Nehlich O, Richards M, Ledger PM, Knecht R. 2018. Stable carbon, nitrogen and sulphur isotope analysis of permafrost human hair from rescue excavations $(2009,2010)$ at the precontact site of Nunalleq, Alaska. Journal of Archaeological Science: Reports 17:950-963.
Bronk Ramsey C. 2009. Bayesian analysis of radiocarbon dates. Radiocarbon 51(1):337-360.

Coachman LK, Aagaard K. 1988. Transport through Bering Strait: annual and interannual variability. Journal of Geophysical Research 93:15535-15540.

Coltrain JB. 2010. Temporal and dietary reconstruction of past Aleut populations: stable- and radioisotope evidence revisited. Arctic 63:391-398.

Coltrain JB, Hayes MG, O'Rourke DH. 2006. Hrdlička's Aleutian population-replacement hypothesis. Current Anthropology 47:537-548.

Coltrain JB, Tackney J, O'Rourke DH. 2016. Thule whaling at Point Barrow, Alaska: the Nuvuk cemetery stable isotope and radiocarbon record. Journal of Archaeological Science: Reports 9:681-694.

Cook GT, Ascough PL, Bonsall C, Hamilton WD, Russell N, Sayle KL, Scott EM, Bownes JM. 2015. Best practice methodology for ${ }^{14} \mathrm{C}$ calibration of marine and mixed terrestrial/marine samples. Quaternary Geochronology 27:164-171.

Darwent, CM. 2011. Archaeological and ethnographic evidence for Indigenous hunting and fishing economies in the North American Arctic and Subarctic. In: Smith BM, editor. The subsistence economies of Indigenous North American Societies. Washington D.C.: Smithsonian Institution Press. p. 31-64.

DeNiro MJ. 1985. Postmortem preservation and alteration of in vivo bone collagen isotope ratios in relation to palaeodietary reconstruction. Nature 317(6040):806-809.

Dumond DE, Griffin DG. 2002. Marine reservoir effect on radiocarbon ages in the eastern Bering Sea. Arctic 55(1):77-86.

Dyke AS, McNeely RN, Hopper J. 1996. Marine reservoir corrections for bowhead whale radiocarbon determinations. Canadian Journal of Earth Sciences 33:1628-1637. 
Dyke AS, Savelle JM, Szpak P, Southon JR, Howse L, Desrosiers PM, Kotar K. 2019. An assessment of marine reservoir corrections for radiocarbon dates on walrus from the Foxe Basin region of Arctic Canada. Radiocarbon 61(1):67-81.

Fitzhugh B, Brown WA. 2018. Reservoir correction for the central and north Kuril Islands in North Pacific context. Radiocarbon 60(2):441-452.

Friesen TM. 2013. North America: Paleoeskimo and Inuit archaeology. In: Ness I, editor. The encyclopedia of global human migration. Chichester, West Sussex: Wiley Blackwell Publishing. p. 1-8.

Grebmeier JM, McRoy CP. 1989. Pelagic-benthic coupling on the shelf of the northern Bering and Chukchi Seas. III. Benthic food supply and carbon cycling. Marine Ecology Progress Series 53:79-91.

Jordan JW, Mason OK. 1999. A 5000 year record of intertidal peat stratigraphy and sea level rise from northwest Alaska. Quaternary International 60(1):37-47.

Keigwin, LD, Donnelly JP, Cook MS, Driscoll NW, Brigham-Grette J. 2006. Rapid sea level rise and Holocene climate in the Chukchi Sea. Geology 34:861-864.

Khassanov BF, Savinetsky AB. 2006. On the marine reservoir effect in the northern Bering Sea. In: Dumond DE, Bland RL, editors. Archaeology in Northeast Asia: on the pathway to the Bering Strait. Eugene: University of Oregon Anthropological Papers No. 65. p. 193-202.

Khim B-K, Lee MJ, Cho HG, Park K. 2018. Surface water productivity and sediment transport by Bering Strait throughflow in the Chukchi Shelf (the western Arctic Ocean) during the Holocene. The Holocene 28(5):814-826.

Krus AM, Jensen AM, Hamilton WD, Sayle K. 2019. A context-appropriate approach to marine ${ }^{14} \mathrm{C}$ calibration: DR and Bayesian framework for the Nuvuk cemetery, Point Barrow, Alaska. Radiocarbon 61(3):733-747.

Kuzmin YV. 2010. Holocene radiocarbon-dated sites in northeastern Siberia: issues of temporal frequency, reservoir age, and human-nature interaction. Arctic Anthropology 47(2):104-115.

Kuzmin YV, Burr GS, Gorbunov VA, Rakov VA, Razjigaeva NG. 2007. A tale of two seas: reservoir age correction values (R, DR) for the Sakhalin Island (Sea of Japan and Okhotsk Sea). Nuclear Instruments and Methods in Physics Research B 259:460-462.

Ledger PM, Forbes V, Masson-MacLean E, Knecht RA. 2016. Dating and digging stratified archaeology in circumpolar North America: a view from Nunalleq, Southwestern Alaska. Arctic 69(4):378-390.

Lee SH, Whitledge TE, Kang S-H. 2007. Recent carbon and nitrogen uptake rates of phytoplankton in Bering Strait and the Chukchi Sea. Continental Shelf Research 27(17): 2231-2249.
Lentfer JW. 1988. Selected marine mammals of Alaska: species accounts with research and management recommendations. Washington D.C.: Marine Mammal Commission.

Martindale A, Cook GT, McKechnie I, Edinborough K, Hutchinson I, Eldridge M, Supernant K, Ames KM. 2018. Estimating marine reservoir effects in archaeological chronologies: comparing DR calculations in Prince Rupert Harbour, British Columbia. American Antiquity 83(4):659-680.

Mason OK. 1998. The contest between Ipiutak, Old Bering Sea, and Birnirk polities and the origin of whaling during the first millennium $\mathrm{AD}$ along the Bering Strait. Journal of Anthropological Archaeology 17:240-325.

Mason OK, Friesen TM. 2017. Out of the Cold: archaeology on the Arctic Rim of North America. Washington D.C.: Society for American Archaeology Press.

Mason OK, Gerlach SC. 1995. Chukchi hotspots, paleopolynyas, and caribou crashes: climatic and ecological dimensions of North Alaska prehistory. Arctic Anthropology 32(1):101-30.

Mason OK, Jordan JW. 1993. Heightened North Pacific storminess during synchronous late Holocene erosion of Northwest Alaska beach ridges. Quaternary Research 40:55-69.

Mason OK, Jensen AM, Rinck B, Alix CM, Bowers PM, Hoffecker JF. 2019. Heightened early medieval storminess across the Chukchi Sea, AD 400-1100: a proxy of the Late Antique Little Ice Age. Quaternary International. doi: 10.1016/j.quaint.2019.01.042.

Mason OK, Ludwig SL. 1990. Resurrecting beach ridge archaeology: parallel depositional records from St. Lawrence Island and Cape Krusenstern, western Alaska. Geoarchaeology: An International Journal 5(4):349-373.

McGhee RJ, Tuck J. 1976. Un-dating the Canadian Arctic. In: Maxwell MS, editor. Eastern Arctic prehistory: Paleoeskimo problems. Memoirs of the Society for American Archaeology 31. Washington D.C.: Society for American Archaeology. p. 6-14.

McNeely R, Dyke AS, Southon JR. 2006. Canadian marine reservoir ages, preliminary data assessment. Open File 5049. Ottawa: Geological Survey Canada.

Misarti N, Maschner H. 2015. The Paleo-Aleut to Neo-Aleut transition revisited. Journal of Anthropological Archaeology 37:67-84.

Naidu AS, Gardner G. 1988. Marine geology. In: Hameedi MJ, Naidu AS, editors. The environment and resources of the Southeastern Chukchi Sea: a review of the scientific literature. Outer Continental Shelf Study, Mineral Management Study 87-0113. p. 29-38.

Naidu AS, Cooper LW, Grebmeier JM, Whitledge TE, Hameedi MJ. 2004. The continental margin of the north Bering-Chukchi sea: concentrations, 
sources, fluxes, accumulation and burial rates of organic carbon. In: Ruediger S, Macdonald R, editors. The organic carbon cycle in the Arctic Ocean. Berlin: Springer Verlag. p. 193-203.

Park RW. 1994. Approaches to dating the Thule Cultural in the eastern Arctic. Canadian Journal of Archaeology 18:29-48.

Pearce C, Varhelyi A, Wastegård S, Muschitiello F, Barrientos N, O'Regan M, Cronin TM, Gemery L, Semiletov I, Backman J, Jakobsson M. 2017. The $3.6 \mathrm{ka}$ Aniakchak tephra in the Arctic Ocean: a constraint on the Holocene radiocarbon reservoir age in the Chukchi Sea. Climate of the Past 13:303-316.

Pickart RS, Moore GWK, Mao C, Bahr F, Nobre C, Weingartner TJ. 2016. Circulation of winter water on the Chukchi shelf in early Summer. Deep Sea Research Part II: Topical Studies in Oceanography 130:56-75.

Pisareva MN, Pickart RS, Spall MA, Nobre C, Torres DJ, Moore GWK, Whitledge TE. 2015. Flow of Pacific water in the western Chukchi Sea: results from the 2009 RUSALCA expedition. Deep Sea Research Part I: Oceanographic Research Papers 105:53-73.

Reimer PJ, Bard E, Bayliss A, Beck JW, Blackwell PG, Bronk Ramsey C, Buck CE, Cheng H, Edwards RL, Friedrich M, Grootes PM, Guilderson TP, Haflidason H, Hajdas I, Hatté C, Heaton TJ, Hoffmann DL, Hogg AG, Hughen KA, Kaiser KF, Kromer B, Manning SW, Niu M, Reimer RW, Richards DA, Scott EM, Southon JR, Staff RA, Turney CSM, van der Plicht J. 2013. IntCal 13 and Marine 13 radiocarbon age calibration curves $0-50,000$ years cal BP. Radiocarbon 55(4):1869-1887.

Reimer RW, Reimer PJ. 2017. An online application for DR calculation. Radiocarbon 59(5):16231627.

Rowland B. 1972. Letter from Bob Rowland to Meyer Rubin, March 29, 1972. Department of Geology, University of California, Davis.

Rubin M. 1974. Report No. W-2768, United States Department of the Interior Geological Survey Laboratory Report, January 1, 1974. Report prepared for Bob Rowland, Department of Geology, University of California, Davis.

Saleeby B, Moss MO, Hays JM, Strahe C, Laybolt DL. 2009. Chapter 8. Faunal Analysis. In: Bowers PM, editor. 2009. The archaeology of Deering, Alaska: final report on the Deering Village Safe Water
Archaeological Program. Report prepared by Northern Land Use Research Inc., Fairbanks, Alaska, for the Native Village of Deering and the City of Deering, Alaska, the Department of Environmental Conservation-Village Safe Water Office and the Alaska State Historic Preservation Office, Anchorage, Alaska. p. 175-200.

Southon JR, Rodman AO, True D. 1995. A comparison marine and terrestrial radiocarbon ages from northern Chile. Radiocarbon 37(2):389-393.

Stuiver M, Pearson GW, Braziunas T. 1986. Radiocarbon age calibration of marine samples back to 9000 cal yr BP. Radiocarbon 28(2B): 980-1021.

Stuiver M, Reimer PJ, Reimer R. 2013. CALIB v7.1 URL: <http://calib.qub.ac.uk/calib/>, accessed January-February 2019.

Tackney J, Coltrain J, Raff J, O'Rourke D. 2016. Ancient DNA and stable isotopes: windows on Arctic prehistory. In: Friesen TM, Mason OK, editors. The Oxford handbook of the prehistoric Arctic. New York: Oxford University Press. p. 51-79.

Taylor RE, Bar-Yosef O. 2014. Radiocarbon dating: an archaeological perspective. Second edition. Walnut Creek: Left Coast Press.

Walsh JJ, McRoy CP, Coachman LK, Goering JJ, Nihoul JJ, Whitledge TE, Blackburn TH, Parker PL, Wirick CD, Shuert PG, Grebmeier JM. 1989. Carbon and nitrogen cycling within the Bering/Chukchi Seas: source regions for organic matter effecting AOU demands of the Arctic Ocean. Progress in Oceanography 22(4):277-359.

Ward GK, Wilson SR. 1978. Procedures for comparing and combining radiocarbon age determinations: A critique. Archaeometry 20:19-31.

West D, Khasanov B, Krylovich O, Hatfield V, Khasanov T, Vasyukov D, Savinetsky A. 2019. Refining the Paleo-Aleut to Neo-Aleut transition using a new DR for the eastern Aleutian Islands, Alaska. Quaternary Research 92(3):1-11.

Wise JL, Comiskey AL, Becker R. 1981. Storm surge climatology and forecasting in Alaska. Anchorage (AK): Arctic Environmental Information and Data Center.

van Klinken GJ. 1999. Bone collagen quality indicators or palaeodietary and radiocarbon measurements. Journal of Archaeological Science 26(6):687-695. 